\title{
Constructing an Islamic Socially Responsible Investment (SRI) Index; The Case of Indonesia
}

\author{
Wiku Suryomurti ${ }^{1}$
}

\begin{abstract}
The aim of this study are: (i) to develop an index based on Islamic stock from List of Islamic Securities (DES) and integrate them with the concept of Socially Responsible Investment (SRI) and (ii) to compare the performance of the constructed index with Jakarta Islamic Index (JII) and SRI Kehati Index. We construct the index using Equally Weighted Method from extensive dataset of more than 300 Islamic securities listed in the List of Islamic Securities (DES). Our result is fairly striking as the Islamic SRI index outperform JII and SRI Kehati as well. We conclude that additional screening with ESG parameter does not impact the index performance. To our knowledge, this research is the first to introduce an Islamic SRI stock Index, particularly in Indonesia. Hence, the result could be a consideration for the Indonesia stock exchange (IDX) stakeholder to introduce this index to the market. Furthermore, the results is expected to help investors in selecting stock that meet the standards of Islamic stocks while also fulfill the ESG criteria into their investment portfolios.
\end{abstract}

Keywords: Islamic finance, Socially Responsible Investments (SRI), Capital markets, Stock Index

Penelitian ini bertujuan untuk: (i) menyusun indeks saham syariah dari daftar efek syariah (DES), dan mengintegrasikannya dengan konsep Socially Responsible Investment (SRI) dan (ii), membandingkan kinerjanya dengan Jakarta Islamic Index (JII) and SRI Kehati Index. Indeks dibentuk menggunakan metode Equally Weighted dari dataset yang terdiri atas lebih dari 300 saham syariah. Hasil perhitungan menunjukan bahwa indeks saham SRI syariah yang terbentuk mampu mengalahkan kinerja JII dan SRI Kehati. Kami menyimpulkan bahwa penyaringan tambahan terhadap saham dengan memasukkan parameter ESG tidak berdampak pada kinerja indeks. Sejauh pengetahuan kami, penelitian ini merupakan yang pertama yang memperkenalkan indeks saham SRI syariah, khususnya di Indonesia. Oleh sebab itu hasil penelitian ini dapat menjadi pertimbangan bagi pemangku kebijakan di Bursa Efek Indonesia untuk mengembangkan indeks ini lebih jauh. Lebih lanjut, hasil penelitian diharapkan dapat membantu investor dalam memilih saham yang termasuk saham syariah sekaligus memenuhi kriteria ESG ke dalam portofolio investasinya.

Kata kunci: Islamic Finance, Socially Responsible Investments (SRI), Capital markets, Stock Index

\footnotetext{
${ }^{1}$ University of Glasgow | wiku.suryomurti@gmail.com
} 


\section{Introduction}

The concept of ethical investment, in which investors use their money to promote action and social activities considered as ethical, has deep roots in the doctrines of the various religions. Islam, Christianity and Judaism, for example, all have a focus on individual moral responsibility to use the money on good things. This religious-based principle has any impact in one's investment decisions over the centuries (Bennett, 2014).

Ethical investment or some experts call responsible investment, means that we incorporate environmental, social and governance (ESG) factors into investment actions. The basic consideration of this concept is that the financial and social returns should be side by side, rather than the opposite. The goal of investment based on ESG is to provide such an investment that not only contribute financially in the form of returns on the portfolio, but also aim to increase the added value in social aspect, such as environment and community friendly. In line with this principle is the green investment concept, which represents the corporate action or investment products that have a minimal impact on the environment. Such products could be stocks, bonds and managed funds which are now being developed throughout the world.

Indonesia as one of the growing emerging market is currently developing its capital market products. Of those products, there are two Islamic stock indexes, Indonesia Sharia Stock Index (ISSI) and Jakarta Islamic Index (JII). ISSI is constructed from the List of Islamic Securities (DES) issued by the National Sharia Board (DSN) together with the Financial Service Authority (FSA) through two screening process based on the business sector and financial selection. While JII consists of 30 stocks selected from DES which have the largest and most liquid capitalization. However, both indexes do not accommodate the investment criteria or parameters based on the concept of Socially Responsible Investment (SRI), whilst the demand for the 
SRI based investment products is growing (Trunow and Linder, 2015). On the other hand, there is SRI Kehati Index, an SRI based index published by Kehati Foundation and Indonesia Securities Commission (IDX). However, the SRI Kehati Index do not meet the Islamic principles since it allow the inclusion of usury related companies. Therefore, we are interested to develop an index based on Islamic stock that also meet the principles of SRI.

In this study, our objectives are basically developed for two reasons. First, the List of Islamic Securities (DES) issued by the Financial Service Authority (OJK) and National Shariah Board (DSN) MUI employ negatives and financial screening only, and does not include positive screening and ESG parameters. Second, research on SRI topic mainly discuss about the prospect of SRI funds or bonds and compare it with the performance of common index or bonds. Finally, the newly stock index will hopefully stimulate further research for other products such as Islamic mutual funds that qualify as socially responsible investment (SRI) funds.

Furthermore, this study would like to identify ESG parameters to screen the list of securities which could be categorised as Islamic and also meet SRI requirements. Another objective is to develop a stock index from the selected stocks, and then compare the performance of the constructed index to other stock index especially the Jakarta Islamic Index and the SRI Kehati Index.

We are also motivated to study this topic because to the best of our knowledge, the Islamic-based SRI stock index in Indonesia is currently nonexistence. Given the importance of this research, it is expected that the result would provide an additional option for investors, especially Islamic investors who would like to improve their investment portfolios. Finally, hopefully this research will lead to a further research on Islamic Stock Index and SRI, and subsequently enrich the literature in the area of capital market and investment. 
The remainder of this paper will be structured as follows. Section 2 presents previous studies related to SRI research and Islamic capital market development. Section 3 will discuss the data and methodology used in this paper. Section 4 will be an analysis of the result and the discussion. Finally, Section 5 conclude the findings and give recommendation for future research.

\section{Literature Review}

\section{Socially Responsible Investment (SRI)}

Ethical investment generally refers to the process of screening to exclude companies involved or engaged in sectors that are considered unethical by investors or contrary to the declaration or international agreement. Exceptions include products such as alcohol, tobacco or cigarettes, pornography, certain weapons, nuclear power plants, and a clear violation of human rights. Or also the companies that do business in countries which had been outlawed (Principles for Responsible Investing, 2012).

The exceptions can also be made on the basis of religion, such as companies that violate the rules or principles of Islamic values. This is the concept of Sharia Investments developed from the principles of the Islamic Financial System (Islamic Finance).

The literature on SRI seemed not all agree with the term "SRI". Some of them defined SRI as "Socially Responsible Investments", "Sustainable Responsible and Impactful investments", or "Social Responsible Investment" (see Bennet and Iqbal, 2013; Renneboog et al, 2008; Center for Islamic Wealth Management, 2015; Ministry of Finance Malaysia, 2013). However, according to Moghul and Safar-Aly (2014), "SRI" is a generic term that includes all types of investments that combine financial objectives of investors with their concern for environmental issues, social and governance (ESG). Thus, this study will use the term SRI to represent all these definitions.

Socially Responsible Investing (SRI) is an investment management approach that integrates the criteria of environmental, social and governance 
or abbreviated as ESG in traditional financial analysis. Despite having only a few templates and rules than the details of Islamic Finance, SRI share a focus on non-economic factors on the economic and social principles. While the Islamic principles, which form the basis of Islamic financial concept, apply the criteria of ethics and extra-financial that symbolizing the slices with the concept of SRI. This concept has similarities with SRI in terms of social responsibility objectives and exceptions to businesses that are considered unethical, for example, gambling, pornography, and weapon manufacturing.

There is currently an SRI based stock index in Indonesia stock exchange published by Kehati Foundation, a nonprofit institution engaged in the social field, especially campaigning environmental conservation for biodiversity preservation in Indonesia. This index is expressed to be following the principle of Sustainable Responsible Investment (SRI) (Kehati, 2015). The index uses 100 basis data with the base year is December 30, 2006 and published by the Stock Exchange under the name of SRI KEHATI Index in 116.946 position. The formation of this index is intended as a materialization program and environmental preservation campaign with a theme of concern for the public, business and capital market investors. Such information provides an overview which companies are giving real support to the environmental and social aspect, prompting other companies to do the same support for the sake of the future of biodiversity in Indonesia.

Theories and studies around Islamic Investment and Socially Responsible Investment (SRI) are growing rapidly in recent years. For example, Marwan and Engku Ali (2015) examines the concept of SRI and analyze its prospects where the instruments covered are the SRI sukuk issued in Malaysia. According to them, the increasing interest in SRI products will also encourage sukuk issuance. However, there are different types of SRI products that may be published as Green Sukuk and SRI Sukuk itself. Furthermore, they discussed the prospects and potential, especially in the promotion of ethical investment and social impact. Finally, they concluded 
that although the financial industry-based SRI is still new, but the potential and request are increasing. As a result, the SRI based sukuk issuance is expected to meet this market and increase the market share of the Islamic finance industry.

A different perspective is presented by Zinkins and Williams (2006) who investigated the compatibility between Islam and the concept of CSR. They studied the principles of Islam with the 10 principles contained in responsible business issued by the UN Global Impact. The study concluded although not specifically mention the Islamic concept of CSR scheme details, that the concept of Islam have a greater impact and more complete. That is because the universality of Islam and codification about ethics are more grounded and valid throughout the period.

Katizikas and Pratama (2013) studied the effect of the CSR report on stock included in the SRI KEHATI index. They examined the importance of a report on the company's CSR as a form of responsibility and to improve the image of the company either voluntarily or as an obligation. The results showed that the quality of a company's CSR disclosures will increase when there is a kind of necessity which is done through the implementation of related regulations in Indonesia.

Similarly, Kurniasari and Warastuti (2015) studied the relationship between CSR and value of the firm listed in SRI Kehati Index. They documented that CSR exposure did not affect the performance of the manufacturing company in the index. However they found positive significant correlation between profitability to firm value.

Bennet and Iqbal (2013) compare the concept of Islamic investment and SRI principles. They argued that both market have a similar framework and should be able to converge each other. Furthermore they believe that Islamic Finance could play an advanced role in supporting sustainability by suggesting sukuk, an Islamic bond to be the instrument. However, they do not discuss the possibility of building stock index that integrate the concept of 
Islamic principles and SRI framework which is needed by Islamic fund managers.

Other literatures however mostly focused on comparing the performance of either Islamic indexes or SRI index with their conventional counterparts. For example, Pranata and Nurzanah (2015) evaluate performance and volatility of Islamic index (JII) and conventional stock index (LQ45) along with their determinant factor variables in Indonesia. They argued that there is no significant difference in performance between those two indexes.

Zulkafli et al. (2016) also performed similar study in which they compare SRI Kehati index and Jakarta Composite Index (JCI). They reported that the SRI index underperformed the JCI. However, it is still producing competitive results in certain years.

From the previous literature review mentioned above, it is likely that there is no previous research on the construction of stock indexes that meet the concept of Islamic stock, while also meets the criteria of ESG parameters which is considered as Social Responsible Investment.

\section{Stock Screening}

This section will discuss about stock screening process in constructing stock index. We think that it is important to highlight this topic since it will shed a light on our understanding of the selection process for constructing an index. We will discuss about them one by one followed by some examples. There are three kind of screening processes: negative screening, positive screening, and financial screening.

Negative screening is the process of selection of the listed companies in stock exchange that can be categorised as containing negative effects (see Sjöström, 2011; Renneboog, Horst and Zhang, 2008; and Diaz, 2016). There are many different versions of negative screening currently carried out by index publisher. However, most of them exclude companies that engage in negative 
sector. For example, National Sharia Board (DSN-MUI) in Indonesia excludes companies from List of Islamic Securities (DES) following these criteria: 1) Activities contrary to Islamic principles; 2) Gambling and the similar industries; 3) Prohibited trading; 4) Usurious Financial Services such as conventional bank and insurance; 5) Sale and purchase risk-containing gharar (uncertainty); 6) Production and distribution of drugs such as narcotics; and 7) Involvement in bribery transactions.

On the other hand, according KEHATI (2015) the negative screening process will exclude companies engaging in following businesses (see also MSCI, 2013): gambling, pesticides, nuclear, weapons, tobacco, alcohol, pornography, and Genetically Modified Organism (GMO). The next screening process is positive screening, which is a screening process based on the criteria of investment product data in positive way. It means that the companies included in the index are those that support the positive program. The higher the degree of a company who promotes positive values in certain criteria, the better the ranking will be. Some examples of positive screening include: The company's management and governance; Attention to the environment; Community empowerment; Business patterns; Human resource Management; and Aspects of human rights.

To gather the data for positive screening, normally the evaluation and selection are based on certain parameters, and done through the analysis of secondary data, financial reports, and questionnaires and through other relevant sources.

This positive screening is now becoming more popular as it encourages companies to engage in activities which support positive effect to societies, environment and enforcing governance. This is the concept where ESG criteria developed by some index publisher like EIRIS in the UK for FTSE4Good indexes, RobecoSam for Dow Jones Sustainability Index (DJSI) in the US, and Kehati Foundation for SRI Kehati Index in Indonesia. 
Finally, the last screening process is based on financial related data or financial screening. In this case, the process of screening by National Sharia Board (DSN), as shown in ISSI and JII are different to the process carried out by Kehati Foundation for SRI Kehati Index.

For stocks to be included in the ISSI or DES, there are only two criteria (OJK, 2014) : Interest-based debt compared to total assets do not exceed 45\% and non-halal revenue compared to total revenue of not more than $10 \%$. Furthermore, for stocks to be included in the JII, the additional processes are selection of 60 stocks with the largest capitalization and further selection of 30 stocks from point before with the largest transaction value. The stage of stock selection for JII is shown on figure 1.

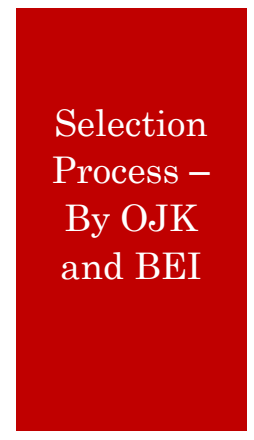

\section{OJK}

Islamic Stock Listed in DES and among ISSI Constituents

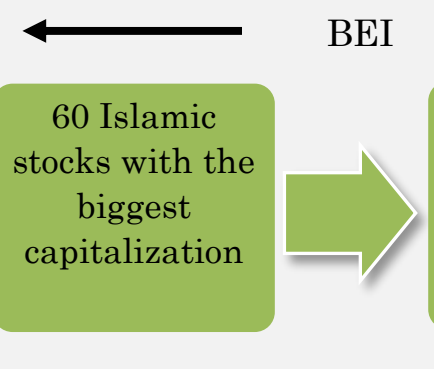

BEI

30 stocks with the highest value of transaction

Figure 1. Screening Process of Jakarta Islamic Index (JII)

As for SRI Kehati index, the financial screening of stocks are as follows: 1) The minimum market capitalization was IDR 1 trillion; 2) Total assets of the company minimum is IDR 1 trillion; 3) Free Float Ratio or exchange-traded stock is $10 \%$ minimum; 4) PER value of the last 6 months should be positive.

Thus there is a real difference between financial screening of Islamic stock index compared with the SRI KEHATI index. Because there is still a possibility that interest-based financial institutions are included in SRI KEHATI Index. Whilst, according to the criteria of National Shariah Board (DSN), it is not permissible. As a result, the SRI Kehati index could be categorized as non-Islamic index. In the next section, we will discuss about the data and methodology used in this study. 


\section{Method}

The data used in this research is secondary data which is categorised as follows: Data of the companies listed in the List of Islamic Securities (DES) between November 2015 and May 2016 published by DSN and Indonesia Securities Commission (BEI). Data of daily closing price, market capitalization and volume of those stocks listed in the List of Islamic Securities starting form January 1st, 2016, will be obtained from Yahoo Finance and other sources, including from the Indonesian Stock Exchange. Information regarding the activities of companies related parameters of environmental, social and governance will be acquired from annual or quarterly financial report, the company's official web site, press releases, and related reports.

Data of selected stock price and trading volume of the shares of the company will be processed to form Islamic SRI stock price index. The method used is EWM or Equally Weighted Method which means the weight of each stock will be divided proportionally with a base date of January 1, 2016 and the initial index of 100. The planned number of shares to be included in the index are between 25 and 30 stocks.

In this research, there will be several stages based on the theoretical framework, the literature review and the deep analysis of the ESG scoring and rating process conducted by international ESG rating agencies.

The stages of this research are collecting data of existing Islamic stocks in the List of Islamic securities issued by the FSA and Indonesia Stock Exchange (BEI); Selecting 60-100 Islamic stocks with the largest market capitalization and liquidity; Choosing the 25 best stocks resulted from the rating obtained from ESG screening process; Calculating the index using Equally Weighted Method; and Comparing the performance of the constructed index with SRI Kehati Index and Jakarta Islamic Index. The detail of the method is shown in figure 2 . 

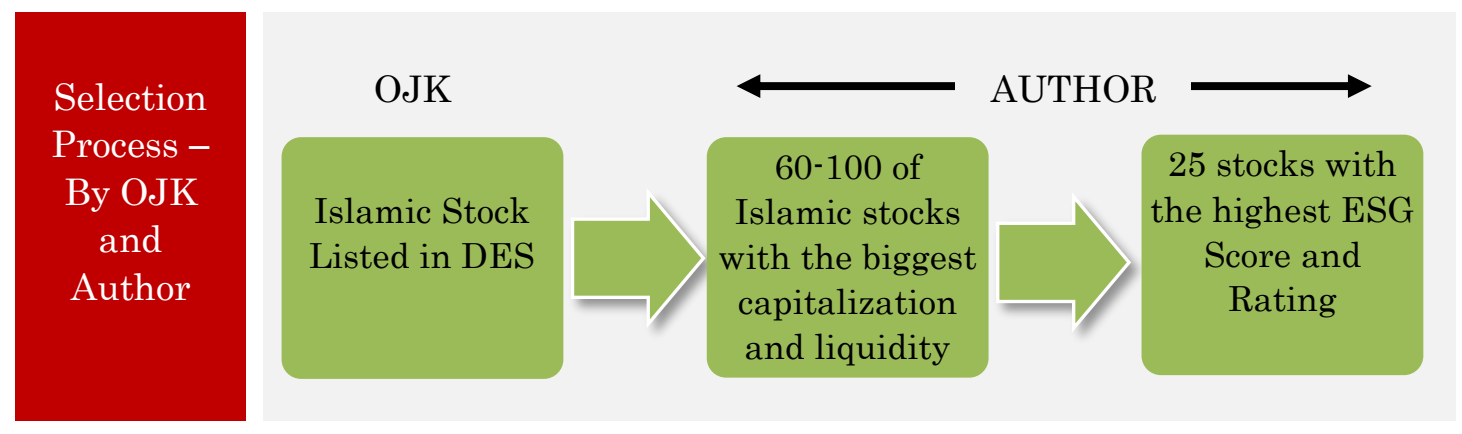

Figure 2. Research Stage

We then select each of the four parameters from each ESG parameter based on a comparison with the selection of ESG parameters conducted by rating agencies such as MSCI ESG, Reputex, Thomson Reuters and RobecoSam. Appendix 1 describes ESG factors used in this study.

The criteria in the selection of these parameters is based on the availability of data and report from companies listed in the List of Islamic Securities. It is expected that each of the criteria for each category is able to represent the standard of selection according to ESG parameters.

Scoring process is the assessment process for each criteria from each ESG category. Assessment is based on the analysis from the financial statements, press releases and other source of information. The range of assessment scales in this study is $0-100$ where 0 is the lowest score while 100 is the highest value. This is slightly different from the ratings agencies such as Reputex that provide value to the $0-10$ scale for each criterion. However, the essence remains the same. The assessment process (scoring) for each criteria is then added up to the total value for each category, subsequently multiplied by its weight. Appendix 2 present the scoring criteria.

From the score obtained in appendix 2, each category will be weighted in which the portion is $30 \%$ for environmental categories, $30 \%$ for social category, and $40 \%$ for the category of governance. This weighting process is also in accordance with the weighting process performed by MSCI ESG rating (MSCI, 2016). The total value of the sum of which is a scale of 100 and then 
normalized to the scale of five, by dividing with 20 . The final rating based on the scale is shown in appendix 3.

The final score obtained from the weighting process then will be arranged in a rating in similar fashion of the rating process on the bond, or sukuk, by using a scale of D to AAA. Appendix 4 below illustrates the distribution of rating based on the score obtained.

\section{Index Calculation}

Stock index calculation is simply done by comparing the market capitalization on the day with a market capitalization starting position and multiplying it by 100 or 1000 base. The formula is as follows:

$\operatorname{Indeks}(H)=\frac{H_{A} \times \operatorname{Vol}_{A}}{H_{A-1} \times \operatorname{Vol}_{A-1}} \times$ basis

where:

$\mathrm{H}_{\mathrm{A}}$ closing price on Day $\mathrm{H}$

Vol A number of outstanding shares A

Basis is set to 100 or 1000

If the results of the screening are 25 stocks, then the stock index is the accumulation or sum of the price of shares outstanding multiplied by the volume of the 25 issuers. Equation (1) can be written as:

$\operatorname{Indeks}(H)=\frac{\operatorname{Cap}(H)}{\operatorname{Cap}\left(H_{-1}\right)} \times \operatorname{basis}$

For example, if the stock price on the basis of the determination of the index is 1000 rupees by the number of outstanding shares 1 million shares, while the closing price today is 1150 rupiah to the number of shares outstanding are the same, then the base index of 100 is obtained stock indexes today by:

Index $=\frac{1.150 \times 1.000 .000}{1.000 \times 1.000 .000} \times 100=115$ 
If there is a change in the market capitalization of the stocks in the index such as rights issues, stock dividends and so on, then the calculation of the index must be adjusted accordingly.

\section{Result and Discussion}

In this section we will discuss the results of the establishment of the Islamic Index SRI based on the methodology that had been developed in the previous section.

We name the constructed index as Tazkia Islamic SRI Index, abbreviated as TISI. The word "Tazkia" is an Arabic term which means "to screen" or "to purify". We choose this name as statement that this index is meant to further purifying the current list of Islamic stock in Indonesia stock exchange which consider business sector and financial ratio per se, whilst our index enhance it by employing additional ESG screening process.

From the results of screening process based on ESG parameters, we acquired 25 stocks from various industrial sectors in Indonesia Stock Exchange. Table 1 show the result of selected stocks.

Table 1. Summary of Selected Stock

\begin{tabular}{cccc|cccc}
\hline No & Emiten & Score & Rating & No & Emiten & Score & Rating \\
\hline 1. & AALI & 3.98 & BBB & 14. & PWON & 4.11 & A \\
2. & ASII & 4.00 & A & 15. & SILO & 3.95 & BBB \\
3. & BSDE & 3.98 & BBB & 16. & SCMA & 4.03 & A \\
4. & ICBP & 3.96 & BBB & 17. & SMGR & 3.95 & BBB \\
5. & INDF & 4.025 & A & 18. & SRIL & 3.93 & BBB \\
6. & INAF & 4.025 & A & 19. & TBIG & 4.025 & A \\
7. & INTP & 3.95 & BBB & 20. & TLKM & 4.25 & A \\
8. & JSMR & 3.98 & BBB & 21. & UNTR & 3.95 & BBB \\
9. & KLBF & 3.98 & BBB & 22. & UNVR & 4.006 & A \\
10. & LSIP & 3.95 & BBB & 23. & WTON & 3.95 & BBB \\
11. & PGAS & 4.025 & A & 24. & WIKA & 3.95 & BBB \\
12. & PPRO & 3.95 & BBB & 25. & WSKT & 3.95 & BBB \\
13. & PTPP & 4.043 & A & & & & \\
\hline
\end{tabular}


In table 1 we can see that there are 25 stocks from ESG screening out of about 300 stock listed in List of Islamic Stock (DES). Most of the selected stocks are from construction industries (WIKA, WSKT, ADHI, PTPP), property developers (ASRI, BSDE, PWON) and manufacturing (ASII, UNVR, INDF, ICBP). We also exclude stocks from interest-based financial institution such as conventional banks, even though they are considered as blue chip stocks and included in SRI KEHATI index.

Results of the selected stock on table 1 is then compared with the list of stocks in the SRI KEHATI index for the period between January $1^{\text {st }} 2016$ until December $31^{\text {st }}$ 2016.There are 13 companies that fit both index: AALI, ASII, INDF, JSMR, KLBF, LSIP, PGN, SMGR, TLKM, UNTR, UNVR, WIKA and WSKT or about $52 \%$ of the total companies. Whilst, when compared with the Jakarta Islamic Index, there are 18 equal stocks, namely AALI, ASII, BSDE, ICBP, INDF, INTP, KLBF, LSIP, PGN, PTPP, PWON, SILO, SMGR, TLKM, UNTR, UNVR, WIKA and WSKT or about $72 \%$ out of 30 stocks.

Next, based on the calculation according to equation (1), we obtained daily data of our Islamic SRI index during the period of one year, between January 1st, 2016 until December 31'st, 2016. The Plot of TISI index chart can be seen in figure 3.

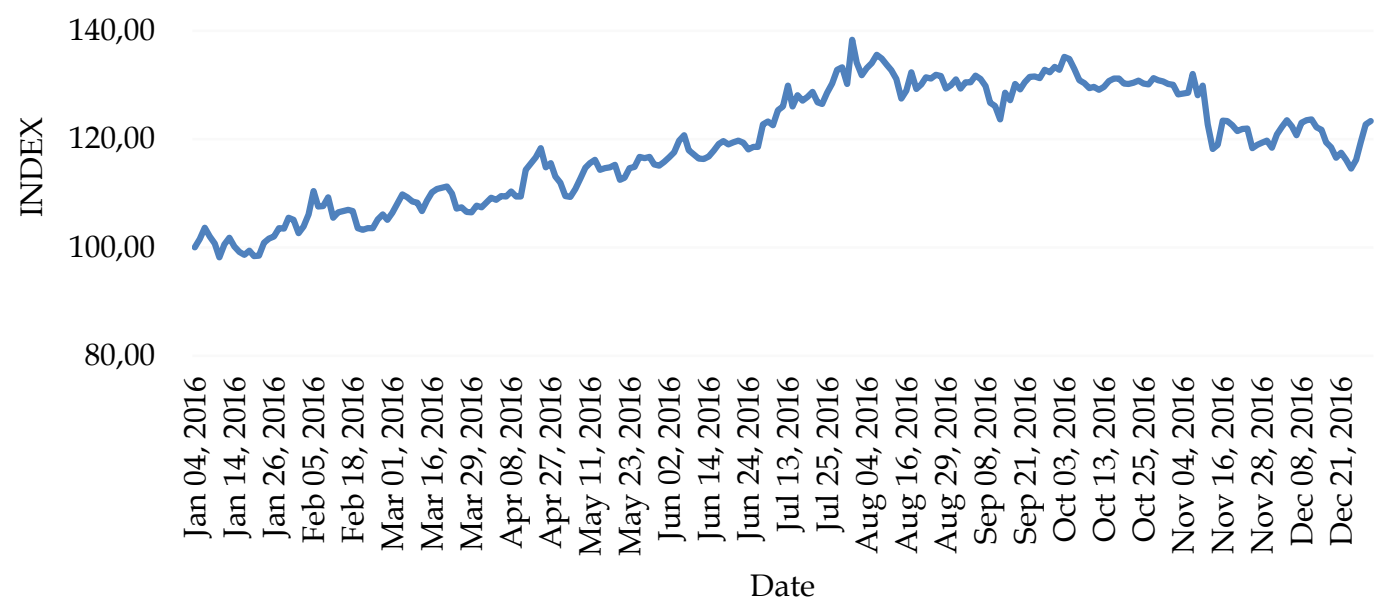

Figure 3. Plot of TISI Index 
The graph shows that during the period, the index increased significantly until reached the peak at position around 140 in August 1', 2016. Then it tends to fluctuate up to a range of 125 by the end of 2016.

When compared with the index SRI Kehati and JII, it is visible that TISI index fluctuation is not too extreme. Comparison of the data movement between the three indexes are plotted in figure 4 .

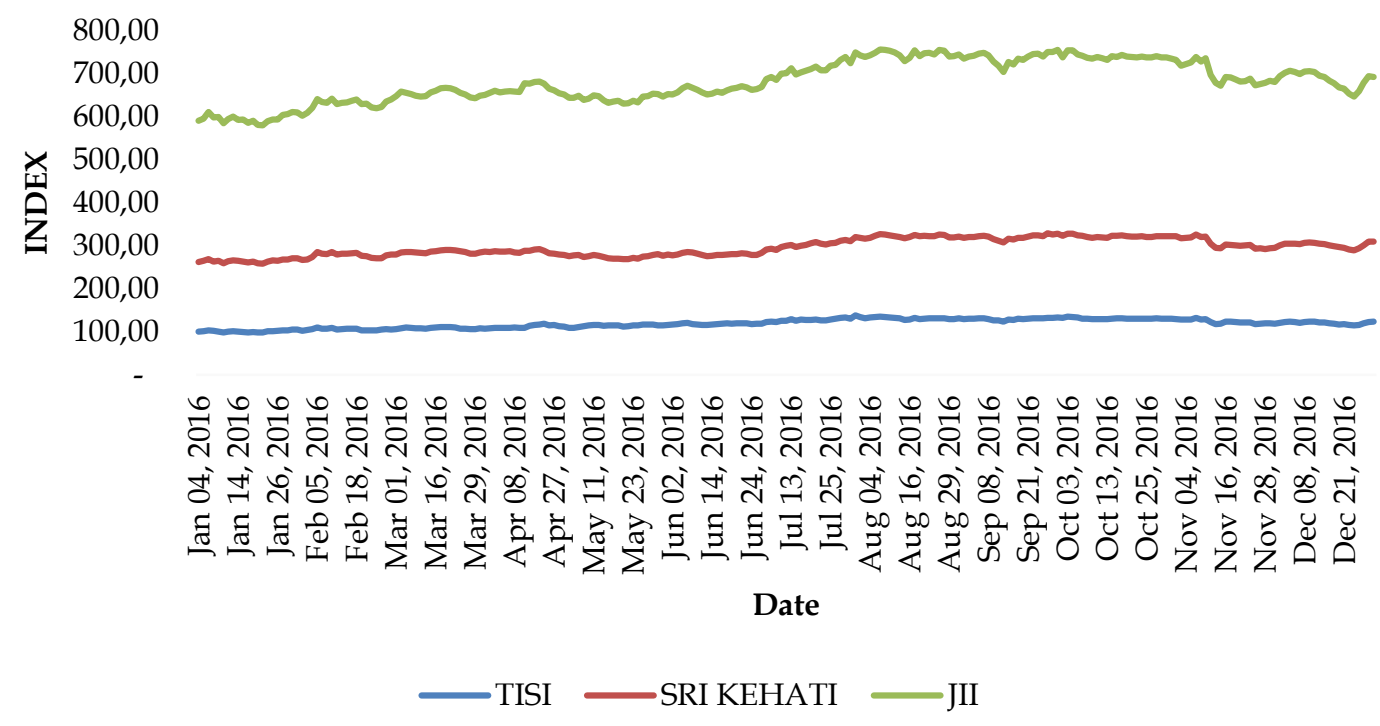

Figure 4. Comparison between TISI, SRI-KEHATI and JII

It is clear from figure 4 that JII index has a higher degree of fluctuation, while TISI index tends to move flatter or stable.

Next is the analysis and discussion of TISI index statistics descriptive data associated with the level of return and risk. Table 2 describes the comparison of return and risk of TISI index against benchmark index SRI Kehati index and Jakarta Islamic Index (JII).

The results in table 2 shows that TISI daily average return rate is higher at $0.09965052 \%$ compared to the SRI Kehati index and JII that each of those two indexes generate a return of $0.076867262 \%$ and $0.073986741 \%$ respectively during the period 1 January 2016 to 31 December 2016.While in the same period, the level of risk which is characterised by standard deviation variable, 
index TISI has the level of risk of $1.5141854 \%$, compared to SRI Kehati and JII which amounted to $1.1516644 \%$ and $1.2003005 \%$ respectively.

Table 2. Mean Return and Risk TISI, SRI Kehati and JII

\begin{tabular}{lllll}
\hline No & Index & Return & Variance & Standard Deviation \\
\hline 1 & TISI & $0,09965052 \%$ & 0,000229276 & $1,5141854 \%$ \\
2 & SRI KEHATI & $0,076867262 \%$ & 0,000132633 & $1,1516644 \%$ \\
3 & JII & $0,073986741 \%$ & 0,000144072 & $1,2003005 \%$ \\
\hline
\end{tabular}

Schroder (2005) also confirmed this finding in his study. He found that 20 of the 29 international SRI index he looked at had higher risk (volatility) than their benchmarks. This suggests that on a risk-adjusted basis, SRI index may underperform conventional index. This might be in line with the theory of investing that with the higher of the potential return, the risk level will also increase. The chart of daily return fluctuations of TISI, SRI KEHATI and JII can be seen in figure 5 .

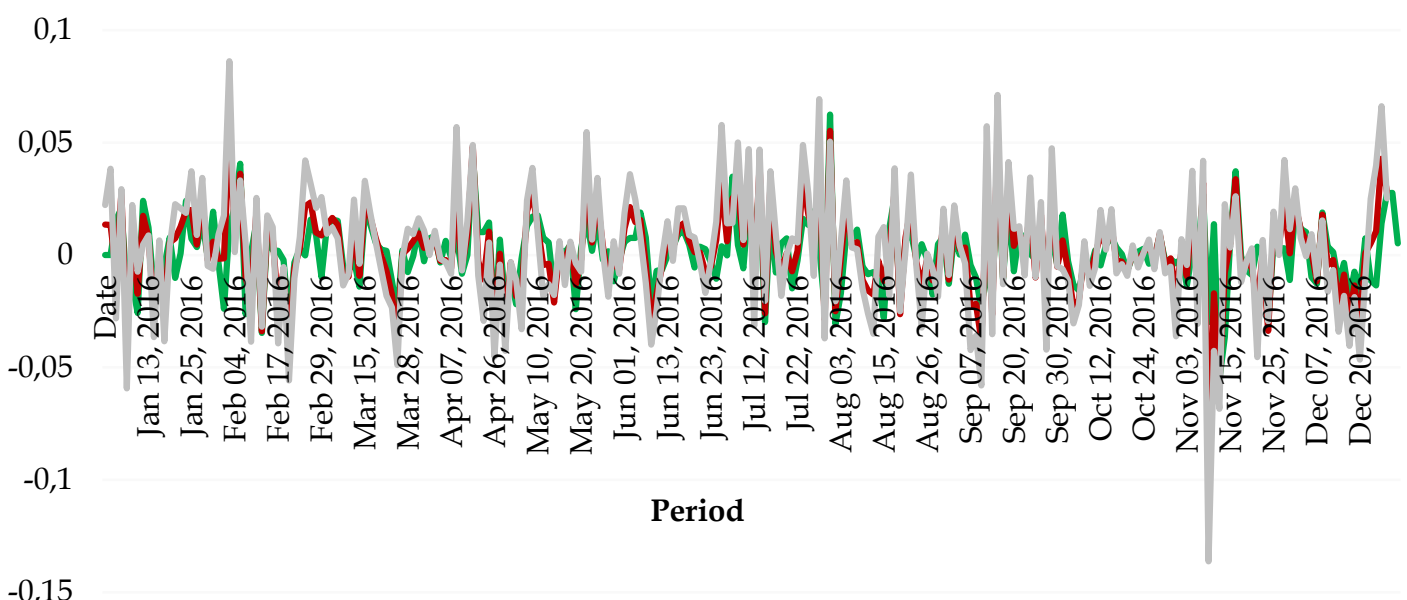

—Daily Return TISI ——Daily Return SRI — — Daily Return JII

Figure 5. Comparison of Daily Return of TISI, Sri Kehati and JII between 1 January 2016 to 31 December 2016

While the growth of the index during the period January 1, 2016 until December 31, 2016 for each index is ilustrated in table 3. 
TIFBR | Tazkia Islamic Finance and Business Review

Table 3. Summary Of Index Growth

\begin{tabular}{cccc}
\hline Remarks & TISI & SRI KEHATI & JII \\
\hline $\begin{array}{c}\text { Beginning of Period } \\
\text { (1 January 2016) }\end{array}$ & 100 & 262.44 & 592.11 \\
$\quad \begin{array}{c}\text { End of Period } \\
\text { (31 December 2016) } \\
\text { \% of Growth }\end{array}$ & 123.360 & 310.19 & 694.13 \\
\hline
\end{tabular}

The table 3 shows that the TISI index has a better performance compared to SRI KEHATI and JII. TISI increased by $23.36 \%$, compared to SRI KEHATI which increased about $18.19 \%$ and JII which increased around $17.23 \%$.

Furthermore, this illustrates that with the inclusion of selection process with ESG parameters, the performance of constructed stock index is not inferior to Islamic based indexes (JII) and to the ESG index without sharia screening (SRI Kehati) either.

\section{Conclusion}

The objective of this paper is to construct a stock index which follows the Islamic principles while also meet SRI criteria. We perform a selection of stock from List of Islamic Securities (DES) using ESG parameters and develop the index using Equally Weighted Method. From the selection and calculation as well as plot a graph of the index, it can be concluded as follows: There are four criteria for environmental categories, four criteria for social categories and also four criteria for the category of governance used in this study to construct sharia stock index that also meet ESG criteria. We use ESG parameters for stock selection by giving score and create a rating similar with bond rating. Next, we construct an index consisting of 25 Islamic stocks which is also considered meeting ESG criteria. Even without a majority of shares classified as blue chip, for example, the conventional banking stocks, the constructed index (TISI) can generate returns that compete with other benchmark index such as SRI KEHATI and the mainstream sharia index JII. 
This result illustrates that by adding a ESG factors parameter-based selection in the companies from the list of Islamic securities, it does not reduce the potential return of the constructed index.

Further Contrary to the result shown by Zulkafli A. H. et al. (2016), our Islamic SRI index outperform both JII and SRI Kehati index. Our result also implies that Islamic SRI index is applicable and competitive to add more diversification in Indonesia capital market. However, investor should be aware that

Our suggestions for further research are: (i) to perform a scoring and rating of ESG parameters from a more comprehensive data set, for example by using a more complete ESG parameters, (ii) to facilitate obtaining a rating that have a fewer elements of bias because of the qualitative factors of the available data, the weighting for each parameter can use artificial intelligence methods such as those used by international rating agencies (MSCI, 2016). Finally, the use of longer period of sample to add more stability.

\section{References}

Bennet, M. and Iqbal, Z. (2013). How Socially Responsible Investing Can Help Bridge The Gap Between Islamic and Conventional Financial Markets. International Journal of Islamic and Middle Eastern Finance and Management, Vol. 6 (3).

Broby, D. and Morgan, L. (2013). What is the Appropriate Index Construction Methodology for African Equity Investment. The Capco Institute Journal of Financial Transformation.

Dow Jones Indices. (2016). Dow Jones Sustainability Indices Methodology.

Holland, J. (2011). A Conceptual Framework for Changes in Fund Management and Accountability Relative to ESG Issues. Journal of Sustainable Finance and Investment, Vol. 1 (2): 159-177

JSE Limited. (2014). SRI Index, Background and Criteria. JSE Limited.

Katsikas, E. and Czafrani, S. (2016). CSR Reporting Practices in Indonesia: A Case Study of Companies Listed on the SRI-Kehati Index. SSRN Paper.

Kehati. (2015). The List of Companies Entered into KEHATI SRI Index in 2009 2015. 
Kurniasari, W., and Warastuti, Y. (2015). The Relationship Between CSR and Profitability to Firm Value in SRI Kehati Index. International Journal of Economic Behaviour, Vol. 5.

Marwan, S. and Ali, E. R. (2015). Sustainable and Responsible Investment; Trend and Prospect. Muzakarah Penasihat Syariah Kewangan Islam 2015.

Moghul, U. F. and Safar-Aly, S. H. K. (2014). Green Sukuk: The Introduction of Islam's Environmental Ethics to Contemporary Islamic Finance. The Georgetown International Environmental Law Review, Vol. 27(1).

MSCI. (2011). Intangible Value Assessment (IVA) Methodology. MSCI ESG Research.

MSCI. (2013). MSCI Global Socially Responsible Indexes Methodology. MSCI ESG Research.

MSCI. (2016). MSCI ESG Governance Metrics. MSCI ESG Research.

Omar, E.N., Jaafar, H., and Osman, M. (2013) Halalan Toyyiban Supply Chain of the Food Industry. Journal of Emerging Economies and Islamic Research.

Pranata, N. and Nurzanah. (2015). Conventional and Islamic Indices in Indonesia: A Comparison on Performance, Volatility, and The Determinants. Indonesian Capital Market Review, Vol. 7 (2): 113-127.

Renneboog, L., Horst, J. T., and Zhang, C. (2008). Socially Responsible Investments: Institutional Aspects, Performance, and Investor Behavior. Journal of Banking and Finance, Vol. 32 (9): 1723-1742.

Schroder, M. (2005). Is there a Difference? The Performance Characteristics of SRI Equity Indexes. Discussion Paper No. 05-50, Centre for European Economic Research.

Sjöström, E. (2011). The Performance of Socially Responsible Investment - A Review of Scholarly Studies Published 2008-2010. SSRN Paper.

Tripathi, V. and Bandhari, V. (2014). Socially Responsible Investing; An Emerging Concept in Investment Management. FIIB Business Review, Vol. 3(4)

Trunow, N. and Linder, J. (2015). Perspectives on ESG Integration in Equity Investing: Risk-Adjusted Investment Performance. Calvert Investment Management Paper.

Zinkin, J. and William, G. (2006). Islam and CSR. A Study of the Compatibility between the Tenets of Islam and The UN Global Compact.

Zulkafli, A.H., Ahmad, Z., and Ermal, E. (2016). The Risk and Return Profiles of SRI in Indonesia: A Study on SRI Kehati Index. Journal of Insurance and Financial Management, Vol. 2 (2): 1-17. 
TIFBR | Tazkia Islamic Finance and Business Review

Volume 11(2), 2017

\section{Appendix}

Appendix 1. ESG Parameter for TISI Index

\begin{tabular}{|c|c|c|c|}
\hline No & Categories & Criteria & Remarks \\
\hline \multirow{4}{*}{1.} & \multirow{4}{*}{ Environment } & Business Category & - $\quad$ Business sector \\
\hline & & Climate Change & - $\quad$ Carbon Emission \\
\hline & & Natural Resources & - $\quad$ Use of renewable energy \\
\hline & & Pollution & - $\quad$ Waste Management \\
\hline \multirow{4}{*}{2.} & \multirow{4}{*}{ Social } & CSR & - $\quad$ CSR Program \\
\hline & & Human Right & $\begin{array}{ll} & \text { Human Right Concern }\end{array}$ \\
\hline & & Health and Safety & - $\quad$ Working Safety \\
\hline & & Product & - $\quad$ Purposes of Product/Service \\
\hline \multirow{4}{*}{3.} & \multirow{4}{*}{ Governance } & Corporate Governance & $\begin{array}{ll}- & \text { Governance } \\
- & \text { Accounting }\end{array}$ \\
\hline & & $\begin{array}{l}\text { Corporate } \\
\text { Behaviour/Integrity }\end{array}$ & $\begin{array}{ll}- & \text { Business Ethics } \\
\text { - } & \text { Business competition }\end{array}$ \\
\hline & & Transparency & - Information openness \\
\hline & & Directors & - $\quad$ Directors Competence \\
\hline
\end{tabular}




\section{Appendix 2. Scoring Criteria}

\begin{tabular}{|c|c|c|}
\hline No & Score & Remarks \\
\hline 1. & $80-100$ & $\begin{array}{l}\text { A score of } 100 \text { is used to express the perfect achievement is proof } \\
\text { positive and the direct impact of the policies, practices and corporate } \\
\text { reports. } \\
\text { While a score between } 80-90 \text { given to companies that reflect the } \\
\text { performance of the relevant criteria, ie proactive and comprehensive } \\
\text { report. This score is also a statement of their management and } \\
\text { monitoring systems are supported disclosure of relevant data and } \\
\text { information. Other high value can also be derived from the } \\
\text { publication will be improvements in the sectors considered with } \\
\text { sufficient data and statistics. }\end{array}$ \\
\hline 2. & $60-80$ & $\begin{array}{l}\text { Scores between } 60 \text { and } 70 \text { indicate the company's performance is quite } \\
\text { high and it gets quite favorably on the criteria that are measured along } \\
\text { with the disclosure of information to the public related to the impact } \\
\text { of the company's operations. }\end{array}$ \\
\hline 3. & $40-60$ & $\begin{array}{l}\text { Score } 40 \text { to } 60 \text { is given as an indication that the company has provided } \\
\text { sufficient information and disclosures related to environmental } \\
\text { factors, social and corporate governance. However, information and } \\
\text { new activities undertaken partial or incidental. Or if done on a regular } \\
\text { basis, but on a small scale or normative. } \\
\text { Often the value can mean compliance ESG conducted as a condition of } \\
\text { regulatory compliance, and not part of the vision or mission of the } \\
\text { company are reflected in the company's operational pattern or policy } \\
\text { of directors and management. Or not / has not become a company } \\
\text { culture. }\end{array}$ \\
\hline 4. & $<40$ & $\begin{array}{l}\text { Scores below } 40 \text { indicate little or no information is available related to } \\
\text { the activities and policies of the company in the implementation of } \\
\text { ESG standards. } \\
\text { Or even the pattern of activity as well as products and services that the } \\
\text { company directly or indirectly have a negative impact on the } \\
\text { environment, social or governance of international standards. }\end{array}$ \\
\hline
\end{tabular}


TIFBR | Tazkia Islamic Finance and Business Review

Volume 11(2), 2017

Appendix 3. ESG Score

\begin{tabular}{ccc}
\hline No & Total Score & Adjusted Score \\
\hline 1 & $90-100$ & $4,5-5$ \\
2 & $80-90$ & $4-4,5$ \\
3 & $70-80$ & $3,5-4$ \\
4 & $60-70$ & $3-3,5$ \\
5 & $50-60$ & $2,5-3$ \\
6 & $40-50$ & $2-2,5$ \\
7 & $30-40$ & $1,5-2$ \\
8 & $20-30$ & $1-1,5$ \\
9 & $10-20$ & $0,5-1$ \\
10 & $<10$ & $<0,5$ \\
\hline
\end{tabular}

Appendix 4. ESG and Score Rating

\begin{tabular}{ccc}
\hline No & Scale & Rating \\
\hline 1 & $4,70-5$ & AAA \\
2 & $4,30-4,69$ & AA \\
3 & $4,00-4,29$ & A \\
4 & $3,71-3,99$ & BBB \\
5 & $3,30-3,69$ & BB \\
6 & $3,00-3,29$ & B \\
7 & $2,70-2,99$ & $\mathrm{C}$ \\
8 & $<2,7$ & D \\
\hline
\end{tabular}

